\title{
ANALISIS FAKTOR-FAKTOR DOMINAN DALAM PEMBENTUKAN CREATIVE TOURISM \\ DAN PENGARUHNYATERHADAP KEPUTUSAN BERKUNJUNG \\ (Survei terhadap Wisatawan Mancanegara Asal Belanda, Jerman dan Perancis yang berkunjung ke D.I. Yogyakarta).
}

\author{
Dendi Supriatna \\ Lili Adi Wibowo \\ Yeni Yuniawati \\ Manajemen Pemasaran Pariwisata FPIPS UPI
}

\begin{abstract}
This research try to find factor to create creative tourism toward visiting decision, research try to find factors can develop european tourist visiting decision to Daerah Istimewa Yogyakarta. Creative tourism have seven variabels latent creative architecture, creative design, creative fashion, creative culinary, creative music, creative performing art, and creative fine art. Used 107 respondent included Netherland, France and Germany who collect from systematic random sampling (mobile sampling) and calculated by confirmaty factor analysis and Structural Equation Modeling, Researcher find 5 to create creative tourism factor: creative architecture, creative design, creative fashion, creative culinary, creative performing art, and the 5 factor of creative tourism can influence toward visiting decision are creative architecture, creative design, creative fashion, creative culinary have positive effec towards visiting decision .
\end{abstract}

Keywords: Creative tourism, keputusan berkunjung, confirmatory factor analysis

\section{PENDAHULUAN}

\subsection{Latar Belakang Penelitian}

Tingkat kunjungan wisatawan yang menurun merupakan issue utama pada suatu destinasi wisata, fenomena penurunan wisatawan ini terus terjadi apabila destinasi wisata tidak memberikan pelayanan yang baik dan tidak menyediakan sesuatu yang diinginkan oleh wisatawan. Keinginan dan kebutuhan akan berwisata wisatawan setiap waktu akan berubah menyesuaikan tren pariwisata masa kini. Dalam penelitian yang telah di lakukan oleh TripAdvisior pada tahun 2014, sebesar 94\% mayoritas wisatawan asing di dunia menjatuhkan pilihan liburannya untuk tempat-tempat rekreasi yang memberikan penawaran wisata menarik, murah atau khusus. Dari hasil penelitian tersebut telah jelas apabila suatu destinasi tidak bisa mengemas produk wisatanya maka setiap waktunya tingkan kunjungan akan semakin menurun.

Tingkat kunjungan wisatawan yang terus menurun akan berdampak buruk pada ekonomi sebuah negara/ destinasi serta berimbas pada penyedia wisata (pekerja wisata). Penurunan kunjungan wisatawan ke suatu destinasi cenderung akan mengakibatkan ekonomi pengembangan di suatu negara/ daerah akan melemah, berkurangnya aktivitas pertemuan antara penyedia jasa wisata dan wisatawan, kamar di suatu hotel akan mengalami penurunan okupansi, serta pelaku wisata (pekerja wisata) baik sebagai pedagang di suatu destinasi wisata akan merasakan berkurangnya tingkat pendapatan (Baugmarten and Jean dalam World Travel \& Tourism Council, 2006: 11-22). Apabila permasalahan mengenai penurunan wisatawan terus dibiarkan maka akan berdampak buruk bagi keberlangsungan suatu destinasi wisata yang melingkupi industri pariwisata (Akomodasi, Food and Beverages, Transportation, dan sentral kerajinan).

Hollensen (2010:154) menjelaskan bahwa keputusan berkunjung wisatawan dipengaruhi oleh psychological variable diantaranya yaitu need, perception, memory dan attitude, dari variabel psikologis tersebut maka dapat diketahui minat wisatawan untuk berkunjung ke suatu destinasi karena wisatawan ingin berkunjung didasari dengan kebutuhan untuk berwisata, ingatan mengenai memori kunjungan sebelumnya, persepsi yang baik mengenai destinasi tersebut dan wisatawan berkunjung kembali dan merekomendasikan kepada kerabatnya apabila di suatu destinasi tersebut memiliki kesan yang baik. 
Permasalahan mengenai penurunan tingkat kunjungan wisatawan telah terjadi di berbagai negara di dunia, D.I. Yogyakarta merupakan salah satu daerah di Indonesia yang mengalami penurunan wisatawan, berdasarkan data dari Dinas Pariwisata D.I. Yogyakarta pada tahun 2013 wisatawan mancanegara yang berkunjung ke D.I. Yogyakarta mengalami penurunan sebesar $11,29 \%$ menjadi 170.398 wisatawan yang di targetkan sebesar 190.000 wisatawan mancanegara berbanding terbalik dengan total kunjungan tahun sebelumnya, wisatawan mancanegara yang berkunjung mengalami peningkatan secara signifikan pada tahun 2012 mencapai 197.751 wisatawan. Berikut data kunjungan wisatawan Mancanegara ke Daerah Istimewa Yogyakarta di tampilkan pada Tabel 1.1 sebagai berikut. KUNJUNGAN WISATAWAN MANCANEGARA KE DAERAH ISTIMEWA YOGYAKARTA TAHUN 2008-2013

\begin{tabular}{|c|c|c|}
\hline Tahun & Jumlah Kunjungan & Pertumbuhan (\%) \\
\hline 2008 & 128.660 & 24,64 \\
\hline 2009 & 139.492 & 8,42 \\
\hline 2010 & 152.843 & 9,57 \\
\hline 2011 & 169.565 & 10,94 \\
\hline 2012 & 197.751 & 16,62 \\
\hline 2013 & 170.398 & 11,29 \\
\hline
\end{tabular}

Sumber: Modifikasi Statistik Pariwisata DIY dan Kemeparekraf

Penurunan kunjungan wisatawan mancanegara ke D.I. Yogyakarta disebabkan beberapa faktor yang berpengaruh pada wisatawan mancanegara yang berkunjung ke DIY di antaranya adalah keamanan, bencana alam, suhu politik di Indonesia, hingga masalah yang menjadi penyebab wisatawan mancanegara masih kurang adalah akses, telah diketahui bahwa direct flight menuju D.I. Yogyakarta dari berbagai negara sangat minim. Hal yang mengakibatkan penurunan wisatawan mancanegra ke D.I. Yogyakarta terdapat pada tingkat pendapatan daerah sektor pariwisata yang disebutkan dalam RKKPD D.I. Yogyakarta menurun pada tahun 2013 adalah sebesar $36,4 \%$ di bandingkan dengan tahun 2012, penurunan tersebut berdampak pada tingkat pengeluaran wisatawan mancanegara terlebih pada wisatawan Eropa, karena setiap tahun penyumbang devisa terbesar sektor pariwisata di D.I. Yogyakarta berasal dari wisatawan Eropa.

Wisatawan Eropa yang sering berkunjung diantaranya adalah Negara Belanda sebesar 32\%, Perancis sebesar 20\% dan Jerman sebesar $11 \%$, ketiga negara tersebut adalah penyumbang devisa untuk sektor pariwisata ke D.I. Yogyakarta berdasarkan Data Statistik Kepariwisataan D.I. Yogyakarta 2013, penurunan kunjungan wisatawan yang berasal dari Eropa berdampak pada hunian kamar baik hotel berbintang mapun hotel melati, juga berdampak pada insdutri transportasi
(Pesawat, Taksi, Kereta Api, dan bus lokal), industri makanan dan minuman, dan pusat kerajinan, oleh-oleh masyarakat lokal.

Dengan adanya permasalahan penurunana wisatawan mancanegara yang berkunjung ke D.I. Yogyakarta maka pemerintah daerah melalui melalui Dinas Pariwsata D.I. Yogyakarta mulai mencanangkan berbagai strategi yang dilakukan untuk menigkatkan kunjungan wisatwan mancanegara.

Strategi tersebut diantaranya adalah membuat slogan "Yogyakarta Never Ending Asia" slogan wisata tersebut bertujuan agar menjadi brain storming wisatawan bahwa dengan berkunjung ke Yogyakarta akan merasakan pengalaman yang baik dan tak akan pernah selesai untuk melupakan Yogkyakarta, selain itu pemerintah juga membagi daerah-daerah kedalam zona wisata yang menarik dintaranya adalah creative tourism, mengadakan event-event bulanan yang menarik, menyediakan paket wisata yang murah untuk wisatawan mancanegara melalui Biro Perjalanan Wisata Yogyakarta dan Tourist Information Center. Dinas Pariwisata D.I. Yogyakarta berharap dengan berbagai strategi tersebut akan meningkatkan kunjungan wisatawan mancanegara. Dari keempat strategi yang telah digagaskan maka creative tourism strategy dipilih karena strategi tersebut adalah gabungan dari beberapa elem dalam memasarkan destinasi pariwisata di D.I. Yogyakarta 
Creative tourism strategy merupakan strategi yang dianggap paling efektif dilakukan oleh pemerintah D.I. Yogyakarta dikarenakan dengan adanya perubahan preferensi wisatawan di berbagai negara di dunia, creative tourism telah dikembangkan sebagai tren wisata yang bertujuan untuk mengembangkan potensi budaya tradisional menjadi kreatif sehingga berpengaruh terhadap kunjungan wisatawan yang datang ke suatu destinasi wisata, konsep creative tourism di D.I. Yogyakarta dimulai pada tahun 2011, strategi tersebut dibentuk berdasarkan potensi yang ada pada daerah wisata di D.I. Yogyakarta dan potensi tersebut terbagi kedalam sub kategori diantaranya creative architecture, creative design, creative fashion, creative culinary, creative music, creative performing art dan creative fine art (Kementrian Pariwisata dan Ekonomi Kreatif, 2011: 55)

Dinas Pariwisata D.I. Yogyakarta mengimplementasiakan faktor pemebentuk creative tourism yaitu creative architecture, creative design, creative fashion, creative culinary, creative music, creative performing art dan creative fine art kedalam bentuk hasil dari budaya yang kreatif sehingga wisatawan dapat merasakan hal yang bersifat budaya dengan sentuhan kreatif seperti wisatawan dapat tinggal di desa wisata dan merasakan kehidupan masyarakat lokal seperti menginap di rumah adat Yogyakarta (creative architecture), melihat dan mencoba membuat wayang kulit (creative design), menggunakan busana tradisional seperti Batik, kain tradisional (creative fashion), mencoba membuat masakan khas Yogyakarta (creative culinary), mendengarkan alunan musik Jawa (creative music), menyaksikan pertunjukan sendratari Ramayana (creative performing art), dan melihat dan membeli oleh-oleh/ pernak-pernik/ patung khas Yogyakarta (creative fine art).

Tren creative tourism merupakan program strategi pemasaran pariwisata Dinas Pariwisata D.I.Yogyakarta, hal ini disebabkan karena pemerintah Pusat dan Daerah ingin memadukan berbagai Industri yang terkait agar menjadi satu kesatuan yang utuh antara Industri pariwisata dan Industri kreatif yang dapat dimanfaatkan oleh pengusaha-pengusaha yang terkait dengan bidang pariwisata maupun kreatif dan dapat menjadi sumber keuntungan untuk devisa negara.
Dengan menerapkan strategi pemasaran pariwisata dengan tema creative tourism Dinas Pariwisata D.I. Yogyakarta mengaharapakan strategi tersebut dapat memenuhi kebutuhan wisatawan mancanegara ketika melakukan aktivitas wisata serta dapat membuat wisatawan mancanegara merasa benar-benar puas dan mendapatkan pengalaman yang menyenangkan yang tidak akan terlupakan saat berkunjung ke D.I. Yogyakarta dan pengalaman tersebut akan menjadi kenangan tersendiri bagi wisatawan dan akan membuat wisatawan merasakan enggamenet. Dengan ini tentunya Dinas Pariwsata D.I. Yogyakarta dapat membangun dan meningkatkan kunjungan wisatawan mancanegara sehingga semakin banyak wisatawan yang melakukan kunjungan ulang serta merekomendasikan kepada kerabat tentang keseruan dan pengalaman terbaik ketika berkunjung ke D.I. Yogyakarta. Namun masih dipertanyakan apakah creative tourism yang dibentuk dengan menggunakan pengukuran sendiri dengan mengkonfirmasi faktor-faktor dominan dapat berpengaruh terhadap keputusan berkunjung wisatawan mancanegara. Oleh sebab itu penulis merasa perlu untuk melakukan penelitian mengenai "Analis Faktor-Faktor Dominan Dalam Pembentukan Creative Tourism Terhadap Keputusan Berkunjung" (Survei terhadap Wisatawan Eropa (Belanda, Perancis, dan Jerman) yang berkunjung ke Daerah Istimewa Yogyakarta).

\subsection{Rumusan Masalah}

Berdasarkan uraian di atas, maka dapat dirumuskan masalah sebagai berikut:

1. Apakah faktor-faktor yang membentuk creative tourism di Daerah Istimewa Yogyakarta (DIY).

2. Bagaimana gambaran keputusan berkunjung wisatawan Eropa ke Daerah Istimewa Yogyakarta (DIY).

3. Bagaimana pengaruh creative tourism terhadap keputusan berkunjung wisatawan Eropa ke Daerah Istimewa Yogyakarta (DIY).

\subsection{Tujuan Penelitian}

Berdasarkan rumusan masalah di atas, maka tujuan dari penelitian ini adalah untuk memperoleh hasil temuan mengenai:

1. Memperoleh temuan mengenai faktor apa saja yang membentuk creative tourism. 
2. Memperoleh temuan mengenai gambaran keputusan berkunjung wisatawan Eropa ke Daerah Istimewa Yogyakarta.

3. Memperoleh temuan mengenai pengaruh creative tourism terhadap keputusan berkunjung wisatawan Eropa ke Daerah Istimewa Yogyakarta.

\subsection{Kegunaan Penelitian}

Kegunaan dari penelitian in terdiri dari dua jenis, yaitu kegunaan teoritis dan kegunaan praktis.

\subsubsection{Kegunaan Teoritis}

Hasil penelitian ini di harapkan dapat memperluas kajian ilmu marketing management, khususnya strategi pemasaran program creative tourism terhadap keputusan berkunjung, serta dapat memberikan masukan bagi peneliti dalam mengembangkan ilmu pemasaran pariwisata.

\subsubsection{Kegunaan Praktis}

Secara praktis hasil penelitian ini diharapkan dapat memberikan masukan bagi Kementrian Pariwisata dan Ekonomi Kreatif dan Dinas Pariwisata Daerah Istimewa Yogyakarta untuk lebih meningkatkan kinerja dalam mengembangkan pariwisata Daerah Istimewa Yogyakarta agar setiap tahunnya selalu mengalami peningkatan kunjungan wisatawan mancanegara, serta diharapkan Wisatwan Mancanegara bisa berkontribusi lebih untuk meningkatkan kunjungannya ke Indonesia khususnya ke Daerah Istimewa Yogyakarta.

\section{KAJIAN PUSTAKA}

\subsection{Konsep Creative tourism}

Richard dan Wilson (2006:15) mengidentifikasikan sejumlah alasan mengapa kreatifitas sekarang lebih populer bila dibandingkan dengan pendekatan budaya tradisional untuk mengembangkan:

1. Budaya sering dikatkan dengan 'budaya tinggi'

2. Sektor budaya tidak dianggap cukup fleksibel atau dinamis

3. Sektor kreatif lebih luas dari sektor budaya, mencakup sub sektor dan memiliki total nilai dan dampak pekerjaan yang lebih besar.

4. Industri kreatif mencakup lebih banyak aspek konsumsi visual (iklan, film, desain, fashion, video game).

5. Perempuan sering memainkan peran penting dalam pengembangan industri kreatif.
Hasil diskusi tersebut menjelaskan mengenai kreatifitas yang melibatkan produksi baru dan menghubungkan hal-hal dalam cara yang baru, serta kreatifitas tidak hanya berhubungan seni, budaya, dan ilmu pengetahuan, tetapi dengan segala bentuk aktifitas manusia. Selain itu, hasil diskusi pun menjelaskan bahwa inovasi merupakan satu pengenalan kreasi baru yang membawa arti ciptaan baru untuk digunakan oleh masyrakat. Hal tersebut dapat terjadi melalui makna kreatif, yaitu dengan produksi produk kreatif. Kreatifitas muncul dalam kondisi yang tepat dan di lingkungan yang tepat.

Pengembangan kreatif yang berhasil merupakan sebuah proses kompleks yang perlu mengakui hubungan antara masa lalu, sekarang dan masa depan antara budaya tinggi dan budaya populer, serta antara ruang dan tempat. Richard dan Wilson (2007: 25) mengidentifikasi elemen kunci dari pengembangan kreatif yang cenderung untuk menjamin kelancaran penggabungan mereka ke dalam skala besar skema pembangunan kota:

1. Clustering - perusahaan kreatif membutuhkan jaringan kolega dan pemasok, dan kelompok yang dilihat sebagai memberikan dorongan untuk kreatifitas individu dan bersama.

2. Consumers- penonton berperan penting untuk industri kreatif, dan dalam banyak kasus kreatif perlu untuk menarik penonton atau konsumen ke lokasi tertentu.

3. Co-markership- dalam rangka untuk berfungsi dengan baik, kelompok kreatif perlu melibatkan para produsen dan konsumen dalam suatu proses Comarkership.

4. Clarity - menarik penonton tergantung pada level jarak penglihatan tertentu dalam susunan populasi, dan kemampuan potensi penonton memandang suatu kreatifitas.ayaan dari untuk berinvestasi dalam kreatifitas, tetapi kepercayaan antara individu yang kreatif juga penting.

5. Confidence - pengembangan harus memiliki kepercayaan diri untuk berinvestasi dalam kreativitas, tetapi kepercayaan diri untuk berinvestasi juga penting.

Kota dan daerah juga harus memiliki kepercayaan diri dalam kemampuan untuk membuat pekerjaan, seperti perkembangan agar bisa sukses. Meningkat tingkat kompleksitas, mungkin tidak mengherankan 
bahwa ada hubungan yang mudah antara pembangunan kreatif dan daerah perkotaan bear.

Seni modern pengembangan kreatif terletak pada transformasi elemen berwujud dari budaya ke dalam 'pengalaman' yang dapat dikonsumsi oleh wisatawan, hal tersebut merupkan proses yang kompleks yang memerlukan koordinasi budaya dan creative hardware, creative software, dan creative orgware (Richards dan Wilson, 2007:18):

1. Creative hardware - Suatu pengembangan destinasi pariwisata melalui creative tourism dengan memperhatikan infrastuktur, ruang untuk produksi kreatif, konsumsi dan prosumtion.

2. Creative software -Suatu pengembangan destinasi pariwisata melalui creative tourism dengan memperhatikan berbagai aspek yaitu atmosfer, fashion, kualitas hidup, pandangan keragaman.

3. Creative Orgware -pengembangan destinasi pariwisata melalui creative tourism dengan memperhatikan berbagai aspek yaitu sektor industri, cluster, peraturan pemerintah.

Kombinasi creative hardware, creative software, dan creative orgware dan digunakan oleh kota dan daerah untuk mengembngkan berbagai pengalaman bagi wistawan maupun penduduk. Richard dan Wilson (2006:19) meringkas kombinasi menjadi tiga jenis dasar pengalaman creative tourism.

1. Creative spectacles, kegiatan kreatif dan inovatif yang kemudian membentuk dasar pengalaman pasif wisatawan sebagai spectacles (produksi pengalaman kreatif untuk wisatawan pasif).

2. Creative spaces, suatu ruangan kreatif yang dihuni oleh materi budaya untuk menarik pengunjung karena suasana yang dinamis

3. Creative Tourism, partisipasi aktif wisatawan dalam kegiatan kreatif, pengembangan keterampilan dan atau tantangan kreatif dapat membentuk dasar dari pengalaman wisata, yang juga dapat menyiratkan tindakan dari creative hardware, creative software, dan creative orgware.

Berdasarkan uraian diatas dapat disimpulkan bahwa creative tourism yaitu merupakan bagian dari pemasaran destinasi pariwisata melalui sumber daya budaya pariwisata. Creative tourism yaitu jenis pariwisata terbaru yang digunakan oleh Kemenparekraf dan BPPI dalam mengembankan produk-produk wisata dan ekonomi kreatif yang memiliki potensi tinggi dan memiliki perbedaan dengan produk-produk lainnya yang serupa.

\subsubsection{Pengertian Creative Tourism}

Konsep creative tourism telah diadopsi dan dikembangkan oleh organisasi ternama dunia yaitu UNESCO yang menyimpulkan upaya mempertahankan kebudayaan dalam Creative Cities Network setelah menyetujui creative tourism sebagai media yang mempromosikan mengenai pemahaman budaya dan tempat. Menurut jurnal dari Richard dan Wilson (2006) menggambarkan kemunculan kreatif-kreatif kebudayaan sebagai sekelompok orang yang merasa tidak puas dengan pandangan-pandangan dunia modern atau tradisional.

Istilah creative tourism bagi para praktisi mungkin sangat identik dikaitkan dengan wisata budaya. Nama creative tourism dicetuskan oleh anggota Association for Tourism and Leisure Education (ATLAS) yang bernama Raymond dan Richards, yang telah menjalankan beberapa proyek untuk European Commission, termasuk pariwisata berbasis seni dan budaya, dan kini telah dikenal dengan pariwisata yang berkelanjutan atau sustainable tourism. Dalam jurnal Richard dan Wilson (2006), pertama kali menidentifikasi pertumbuhan creative tourism sebagai perluasan atau reaksi kepada pariwisata kebudayaan. Mereka menegaskan bahwa berbeda sekali dengan sebagian besar pariwisata kebudayaan, konsumen kreatif semakin sering mencari pengalaman-pengalaman yang lebih menarik dan interaktif yang dapat membantu mereka di dalam perkembangan pribadi dan kreasi identitasnya dengan meningkatkan modal kreatif mereka.

Richard dan Raymond (2000:18) pertama kali menciptakan creative tourism sebagai hasil ketidakpuasan dari produk wisata budaya tradisonal. Oleh karenanya mereka mengembangkan konsep creative tourism dimana kreatifitas bermain peran hal-hal yang perlu dalam proses produksi budaya dan konsumsi.

Richards dan Wilson mendefinisikan creative tourism melalui surat kabar ATLAS (2007:16-20) yaitu:

Tourism which offers visitors the opportunity to develop their creative 
potential through active participation in courses and learning experiences which are characteristic of the holiday destination where they are undertaken

Dalam jurnal Campbell (2010) mendefinisikan creative tourism sebagai kegiatan wisata yang menawarkan pengunjung suatu pengajaran kreatif (termasuk seni, kerajinan lokakarya masakan), dengan kesempatan untuk tinggal di akomodasi berkualitas tinggi, dan berhubungan dengan orang lokal di tempat tujuan berbeda.

Definisi creative tourism pun didefinisikan oleh UNESCO sebagai:

"Travel directed towards an engaged and authentic experience, with participative learning in the arts, heritage, or special character of a place, and it provides a connection with those who reside in this place and create this living culture"

Badan Promosi Pariwisata Indonesia (BPPI) dalam Rencana Strategi Pemasaran Pariwisata 2012-2015 menjelaskan bahawa ada beberapa hal yang harus digaris bawahi dalam mendefinisikan pariwisata kreatif, yaitu:

1. Mempertimbangkan pengalaman otentik dirasakan oleh wisatawan.

2. Adanya pembelajaran aktif parcipatory, interaktif dan informal.

3. Berikan kesempatan bagi wisatawan untuk menggunakan potensial kreatif mereka dalam mengkonsumsi produk pariwisata.

4. Apakah tidak produksi masal, tetapi dilakukan dalam kelompok kecil.

5. Memiliki hubungan yang kuat dengan masyarakat sebagai pelaku utama dalam kegiatan.

Berdasarkan beberapa definisi mengenai creative tourism yang telah dikemukakan oleh para ahli di atas mengenai creative tourism merupakan sebuah kegiatan pariwisata dimana para wisatawan dapat mengembangkan potensi kreatif merka melalui partisipasi aktif didalam pengalaman belajar seni, warisan atau karakter khusus dari tempat yang dikunjungi.

Mengidentifikasi prinsip-prinsip tersebut adalah variabel utama creative tourism dari bentuk pariwista lain, seperti wisata budaya atau ekowisata. Jika dilihat dari bentuk-bentuk pariwisata yang bersaing satu sama lain, creative tourism harus dipandang sebagai perangkat tambahan positif dari bentuk pariwisata lain.

\subsection{Konsep Keputusan Berkunjung}

Keputusan berkunjung dalam penelitian ini diadaptasi dari keputusan pembelian karena tahap-tahap yang dilewati oleh wisatawan dalam menentukan pilihan destinasi wisata sama dengan tahap keputusan pembelian pada umumnya. Terdapat beberapa definisi dari keputusan pembelian oleh para ahli pemasaran, seperti yang diungkapkan oleh Kotler dan Keller (2012:170) bahwa keputusan pembelian "In the evaluation stage, the consumer forms preferences among the brands in the choice set and may also form an intention to buy the most preferred brand." Berbeda dengan Venugopal (2010:106) yang mendefinisikan keputusan pembelian seperti berikut,

Purchase Decision is once evaluation is done, it could convert into a purchase if the goods or service are available at the right time in the right place, in the right quantity and right form (form utility, time utility, place utility and possession utility).

Definisi tersebut mengemukakan bahwa evaluasi akan berubah menjadi keputusan pembelian, bila barang atau jasa sudah tersedia pada waktu yang tepat dan bentuk yang tepat. Pendapat lain mengenai keputusan pembelian menurut Alma (2008:63) sebagai berikut, "Keputusan pembelian adalah suatu keputusan yang dilakukan oleh pelanggan yang dipengaruhi oleh kebudayaan, kelas sosial, keluarga dan referensi grup yang akan membentuk suatu sikap pada diri individu kemudian melakukan pembelian”.

Keputusan pembelian menurut Schiffman, Kanuk (2004, p.547) adalah pemilihan dari dua atau lebih alternatif pilihan keputusan pembelian, artinya bahwa seseorang dapat membuat keputusan, haruslah tersedia beberapa alternatif pilihan.

Namun berbeda dengan pengertian dari jurnal Analysis of the Impact of Brand Assets on the Buying Decisions of Final Consumers Brand of Iran's Milk Industry Company (Pegah) oleh Doomstar, Akhlagh, Abadi (2012:4) yang menyatakan bahwa.

Consumer decision-making process can sometimes be a complicated process and consumers can rely on the information about specific products and brands and their consumer experience gathered reach purchase decision making. 
Menurut pengertian tersebut proses pengambilan keputusan pelanggan kadangkadang bisa menjadi proses yang rumit dan pelanggan dapat mengandalkan informasi tentang produk dan merek dan pengalaman pelanggan mereka berkumpul mencapai pembuatan keputusan pembelian.

Berdasarkan beberapa pengertian di atas berarti keputusan pembelian adalah ketika seorang pelanggan akan memutuskan untuk membeli bila sebelumnya mereka telah melakukan evaluasi dari beberapa informasi dan alternatif pilihan mengenai produk atau brand tertentu sehingga akhirnya mencapai sebuah pembuatan keputusan untuk membeli.

\section{Model Keputusan Berkunjung}

Proses keputusan berkunjung bagi wisatawan memerlukan beberapa alternatif pilihan destinasi wisata yang akan dikunjungi serta memerlukan suatu upaya dari atraksi wisata agar dapat sampai ke wisatawan dengan beberapa atraksi yang mampu mendatangkan wisatawan yang terus meningkat. Salah satu model consumer decision making yang dikemukakkan oleh Hollensen (2010:148), mengatakan bahwa perusahaan juga harus memiliki kekuatan dalam peran untuk mendisain dan menyediakan stimulan untuk memutuskan berkunjung. Proses secara dinamis dari interaksi antara pembeli dan lingkungan. Berikut merukpakan gambar dari model consumer decision making disajikan dalam Gambar 2.5 berikut:

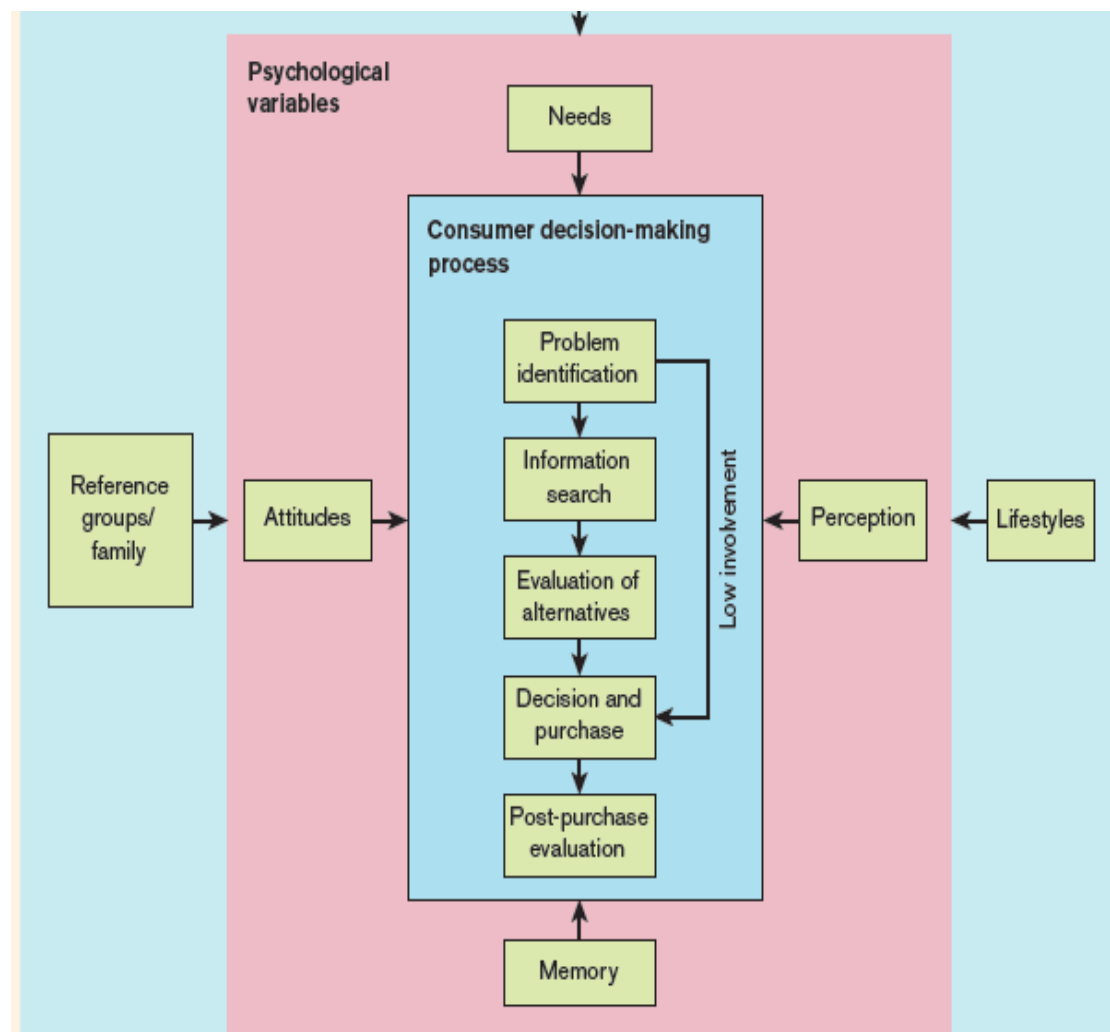

Sumber: Svend Hollensen, 2010

GAMBAR 2.2

MODEL CONSUMER DECISION MAKING SPR

Menurut Hollensen (2010:117-118) mengatakan bahwa pengaruh consumer descision making memiliki usaha yang sama dengan konsumen yang lainnya. Beberapa hal yang penting yaitu variabel psychological yang menjadi pengaruh dalam consumer descision making melingkupi needs, perception, memory dan attitudes. Karakteristik konsumen personal seperti demographic dan lifestyle variable. Pengaruh dari faktor psychological adalah sebagai berikut:

\section{Needs}

Kebutuhan adalah sesuatu yang dubutuhkan oleh semua manusia baik secara psikologis maupun secara lahiriah, kebutuhan lahir dari apa menjadi suatu kebiasaan yang harus dipenuhi. Berikut 
merupakan penjelasan menurut Maslow (1970) mengenai kebutuhan.

Abraham Maslow's famous classification (1970) is often used by marketers to help categorise consumer desires. According to Maslow, five basic needs underlie most human goals: Physiological: food, water, warmth, sleep; Safety: security, protection; Love and belonging: family, friendship and acceptance; Esteem: prestige, status, self-respect; Selfactualisation: self-fulfilment and personal enrichment.

\section{Perception}

Persepsi merupakan dimensi yang kedua yang dikemukakan oleh Hollensen, persepsi lahir dari apa yang wisatawan interpretasikan mengenai beberapa kawasan destinasi pariwisata yang akan atau telah dikunjungi, wisatawan melakukan keputusan berkunjung kesuatu destinasi didasari oleh keinginan dan persepsi wisatawan terhadap destinasi pariwisata. Berikut adalah pengertian persepsi menurut Hollensen (2010:154)

Perception is the process by which a person selects, organises and interprets information. When consumers collect information about a high-involvement product they follow a series of steps, or a hierarchy of effects. Exposure to a piece of information, such as a new product, an advert or a friend's recommendation, leads to attention, then to comprehension, and finally to retention in memory. Once consumers have fully perceived the information, they use it to evaluate alternative brands and to decide which to purchase.

\section{Memory}

Dalam stage ketiga dalam proses keputusan berkunjung adalah dilihat dari ingatan wisatawan terhadap suatu destinasi, ingatan tersebut berdasarkan dua faktor, yaitu faktor ketika wisatawan tersebut sudah pernah berkunjung ke destinasi tersebut atau mendengar cerita atau rekomendasi yang baik dari kerabat mengenai destinasi sehingga wisatawan tersebut mengingatnya dan ingin melakukan kunjungan wisata. Berikut penjelasan memory menurut Hollensen (2010:154).

Consumers are also selective in what they remember. Thus, they tend to retain information that supports what they believe. There are different theories of how the human memory operates, but most agree that it works in two stages. Information from the environment is first processed by the short-term memory, which forgets most of it within 30 seconds or less because of intention or displacement by new incoming information. Some information, however, is transferred to longterm memory, from where it can be retrieved later. In longterm memory, a vast amount of information may be held for years or even indefinitely. It remains there until replacement by contradictory information through a process called interference. Consumers are bombarded with promotional messages. Marketers hope that the more often their brand name is seen, the more likely consumers will be to process information about it.

Berdasarkan penjelasan di atas mengenai memori yang dijelaskan oleh Hollensen (2010:154) dapat disimpulkan bahwa ingatan wisatawan mengenai suatu destinasi pariwisata, bahwa wisatawan dapat mengingat apa yang dirasakan didukung dari apa yang dipercayai mengenai destinasi pariwisata yang lebih diingat oleh wisatawan adalah mengenai hal yang positif dan hal yang negatif mengenai destinasi pariwsata yang telah dikunjungi. Dimensi dari memori tersebut dapat dijadikan untuk alat untuk mengukur untuk keputusan berkunjung wisatawan.

\section{Attitudes}

Perilaku merupakan stage yang keempat dalam proses keputusan berkunjung, perilaku wisatawan dapat memiliki tiga komponen yang dapat mempengaruhi perilaku wisatawan untuk keputusan berkunjung yaitu cognitive, affective dan behavioral. Untuk lebih jelas berikut pengertian attitude menurut Hollensen (2010:117.

An attitude is a positive or negative feeling about an object (say, a brand) that predisposes a person to behave in a particular way toward that object. Attitudes are often described as consumer preferences - a like or dislike for products or their characteristics.Marketers usually think of attitudes as having three components: cognitive, affective and behavioural. The cognitive aspect refers to knowledge about product attributes that are not 
influenced by emotion. The affective component relates to the emotional feelings of like or dislike. The behavioural element reflects the tendency to act positively or negatively. In other words, attitudes toward purchasing a product are a composite of what consumers know about its attributes.

Dimensi yang digunakan penulis menggunakan dimensi dari Hollensen (2010: 117-118) yaitu need, perception, memory dan attitude, alasan menggunakan dimensi tersebut karena dimensi keputusan berkunjung mampu mengukur semua tahapan pembuat keputusan, selain itu dimensi tersebut sesuai dengan kondisi di daerah yang diteliti saat ini.

Penjelasan di atas merupakan inti dari apa yang akan dibahas mengenai empat keputusan berkunjung yaitu need, perception, memory, dan attitude.

\subsection{Pengaruh Creative Tourism Terhadap Keputusan Berkunjung}

Pengaruh creative tourism terhadap keputusan berkunjung bahwa creative tourism merupakan program strategi pemasaran pariwisata yang dijalankan oleh pemerintah Indonesia melalui Badan Promosi Pariwisata Indonesia (BPPI), creative tourism yang baik akan membuat konsumen berpikir mengenai sebuah merek atau produk, serta jika pengaruh yang ditimbulkan dari creative tourism seperti menyediakan aktifitas wisata yang menarik, memiliki sutua nilai yang lebih dari destinasi lain secara tepat maka akan mengalihkan wisatawan sehingga membuat keputusan untuk berkunjung ke suatu destinasi pariwisata dengan adanya program creative tourism yang telah dijalankan oleh perusahaan khususnya BPPI. Richard and Wilson mendefinisikan creative tourism sebagai :

Tourism which offers visitors the opportunity to develop their creative potential through active participation in courses and learning experiences which are characteristic of the holiday destination where they are undertaken

Sedangkan menurut Olson at all dalam jurnalnya menjelaskan bahwa:

In order to profit from the creative business model, Bulgarian small municipalities and local government have to create strategies for developing creative tourism products. Practice has shown that plans and programs are not enough to attract visitors (domestic or international) if strategy and resources exist. A strong marketing, regional and local branding have to be created as well in order to establish the creative destinations as choice for cultural tourism to the country. However, the drive for creative tourism development must come from the tourism business as tourist companies have to create, sell and deliver the creative tourism products and services, not EU or governmental policies.

Berdasarkan penjelasan di atas dijelaskan bahwa creative tourism dapat berpengaruh terhadap keputusan berkunjung wisatawan ke suatu destinasi namun hal tersebut harus didukung oleh beberapa industri yang terkait dalam memasarkan destinasi pariwisata melalui program creative tourism diantaranya yaitu proses memasarkan dengan tepat sasaran, merek yang kuat dari suatu destinasi tersebut apabila hal tersebut telah berjalan dengan baik maka telah dipastikan bahwa creative tourism dapat berpengaruh terhadap keputusan berkunjung.

Berdasarkan pendapat para ahli yang telah mengemukakan pengaruh creative tourism terhadap keputusan berkunjung, maka dapat ditarik kesimpulan bahwa program creative tourism yang baik dapat berpengaruh terhadap keputusan berkunjung.

\subsection{Kerangka Pemikiran}

Untuk menjawab rumusan masalah maka akan dijawab oleh kerangka berfikir sebagai berikut: 


\begin{tabular}{|c|c|}
$\begin{array}{c}\text { Destination Marketing } \\
\text { Pike }\end{array}$ & $\begin{array}{c}\text { Tourism Marketing Strategy } \\
\text { Kemeparekraf dalam Rencana Strategi } \\
\text { Kepariwisataan } \\
(2008: 24)\end{array}$ \\
& $\begin{array}{l}(2011-2015) \\
\text { 1. } \text { Low season tourism }\end{array}$ \\
& 2. Green Tourism \\
& 3. Creative Tourism
\end{tabular}

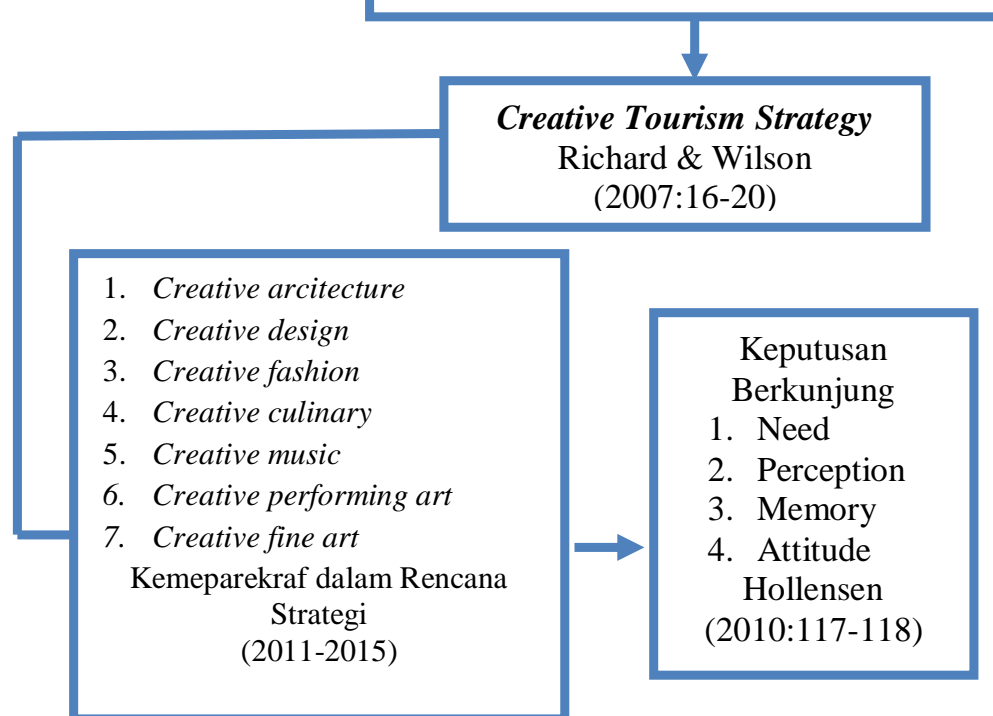

\subsection{Hipotesis}

Berdasarkan pemaparan teori yang telah dijelaskan bhawa terdapat pengaruh creative tourism terhadap keputusan berkunjung, maka hipotesis dalam penelitian ini adalah:

Terdapat faktor-faktor yang dominan dalam pembentukan creative tourism yang terdiri dari creative architecture, creative design, creative fashion, creative culinary, creative music, creative performing art dan creative fine art. Serta terdapat pengaruh yang signifikan antara faktor-faktor creative tourism yang telah dibentuk terhadap keputusan berkunjung.

\section{METODE PENELITIAN}

\subsection{Objek Penelitian}

Penelitian ini mengenai upaya meningkatkan kunjungan wisatawan mancanegara (Negara Belanda, Perancis dan Jerman) yang berkunjung ke D.I. Yogyakarta melalui program creative tourism. Adapun yang menjadi variabel bebas (independent variable) adalah creative tourism (X) dan masalah yang menjadi variabel terikat (dependent variable) yaitu keputusan berkunjung (Y).

Creative tourism (independent variable) meliputi tujuh koonstruk laten yang terdiri dari creative architecture, creative design, creative fashion, creative culinary, creative music, creative performing art, dan creative fine art. Sedangkan keputusan berkunjung (dependent variable) terdiri dari empat indikator yaitu need, perception, memory dan attitude. Ketujuh variabel creative tourism tersebut diukur oleh indikatorindikator yang terdiri 28 indikator dimana setiap variabel diukur oleh empat indikator. Sedangkan keempat dimensi keputusan berkunjung terdiri dari 12 indikator dimana setiap variabel diukur oleh tiga indikator. Unit analisis dari penelitian ini adalah Wisatawan Mancanegara meliputi Negaranegara Benua Eropa yang berkunjung ke Daerah Istimewa Yogyakarta (DIY)

Penelitian ini dilakukan satu kali dalam jangka waktu kurang dari satu tahun, maka metode yang digunakan adalah cross sectional method yaitu metode penelitian dengan cara mempelajari objek dalam satu kurun tertentu (tidak berkesinambungan dalam jangka waktu panjang).

\subsection{Metode Penelitian}

Berdasarkan variabel=variabel yang diteliti maka metode penelitian yang 
dipergunakan adalah metode deskriptif dan verifikatif.

\subsection{Metode Penaliran Sampel}

Ukuran sampel yang dihitung dengan menggunakan rumus Yamane. Berdasarkan rumus tersebut, dengan derajat kebebasan $10 \%$, maka jumlah responden yang dijadikan ukuran sampel dalam penelitian ini adalah sebanyak 100 responden.

\subsection{Teknik Pengumpulan Data}

Teknik pengumpulan data yang digunakan oleh penulis adalah Kuesioner, Studi Literatur, Wawancara, dan Observasi

\subsection{Pengujian Validitas dan Reliabilitas}

Sebelum didistribusikan kepada responden, instrumen penelitian yang berupa kuesioner diuji terlebih dahulu. Uji yang dilakukan meliputi uji validitas dan uji reliabilitas. Hasil menunjukkan bahwa instrumen valid dan reliabel.

\subsection{Pengujian Hipotesis}

Proses untuk menguji hipotesis dimana metode analisis yang dilakukan dalam penelitian ini adalah metode analisis verifikatif, maka dilakukan analisis Structural Equation Modeling (SEM), dalam analisis SEM makan akan diketahui faktorfaktor dominan apa saja yang mampu membetuk variabel $\mathrm{X}$ dengan metode confirmatory factor analysis (CFA), setelah melakukan proses CFA makan akan du uji dengan menguji keseluruhan model antara creative tourism terhadap keputusan berkunjung. Apabila model tersebut bisa dikatakan fit makan proses terakhir adalah path diagram utuk menguji pengaruh creative tourism terhadap keputusan berkunjung.

\section{IV.HASIL PENELITIAN DAN} PEMBAHASAN

\subsection{Hasil Analisis Faktor-faktor Dominan Pembentuk Creative Tourism}

Hasil mengenai faktor-faktor dominan apa saja yang membentuk creative tourism yang terdiri atas tujuh variabel dan 28 indikator dapat diyantakan dalam tabel tersebut.

TABEL 4.1

KESIMPULAN HASIL CONFIRMATORY FACTOR ANALYSIS VARIABEL CREATIVE Tourism

\begin{tabular}{|c|c|c|c|c|}
\hline No. & Variabel Laten & Indikator & $\begin{array}{c}\text { Nilai } \\
\text { Loading } \\
\text { Factor }\end{array}$ & Kesimpulan \\
\hline \multirow[t]{3}{*}{1.} & \multirow{3}{*}{$\begin{array}{c}\text { Creative } \\
\text { Architecture }\end{array}$} & 1. Hotel Buildings Architecture & 0,566 & Valid \\
\hline & & $\begin{array}{l}\text { 2. Museum Buildings } \\
\text { Architecture }\end{array}$ & 0,534 & Valid \\
\hline & & $\begin{array}{c}\text { 3. The Uniqueness Of } \\
\text { Architecture }\end{array}$ & 0,511 & Valid \\
\hline \multirow[t]{4}{*}{2.} & \multirow[t]{4}{*}{ Creative Design } & 1. Theme Park Design & 0,59 & Valid \\
\hline & & 2. Wayang Kulit Design & 0,597 & Valid \\
\hline & & 3. Public Spaces Design & 0,568 & Valid \\
\hline & & 4. Signage Design & 0,511 & Valid \\
\hline \multirow[t]{3}{*}{3.} & \multirow[t]{3}{*}{ Creative Fashion } & $\begin{array}{l}\text { 1. Diversity Of Traditional } \\
\text { Fashion }\end{array}$ & 0,667 & Valid \\
\hline & & $\begin{array}{c}\text { 2. Design Of Traditional } \\
\text { Fashion }\end{array}$ & 0,668 & Valid \\
\hline & & $\begin{array}{l}\text { 3. Traditional Fashion Have } \\
\text { Good Quality }\end{array}$ & 0,522 & Valid \\
\hline 4. & $\begin{array}{l}\text { Creative } \\
\text { Culinary }\end{array}$ & $\begin{array}{c}\text { 1. Learn To Cook Yogyakarta } \\
\text { Food }\end{array}$ & 0,605 & Valid \\
\hline
\end{tabular}




\begin{tabular}{|c|c|c|c|c|}
\hline No. & Variabel Laten & Indikator & $\begin{array}{c}\text { Nilai } \\
\text { Loading } \\
\text { Factor }\end{array}$ & Kesimpulan \\
\hline & & 2. Traditional Cuisine & 0,588 & Valid \\
\hline & & $\begin{array}{c}\text { 3. Traditional Dish Suits My } \\
\text { Taste }\end{array}$ & 0,595 & Valid \\
\hline \multirow[t]{4}{*}{5.} & \multirow{4}{*}{$\begin{array}{c}\text { Creative } \\
\text { Performing Art }\end{array}$} & 1. Creativity Performance & 0,59 & Valid \\
\hline & & 2. Qulity Performance & 0,597 & Valid \\
\hline & & $\begin{array}{l}\text { 3. Learn Yogyakarta } \\
\text { Traditional Performing Arts }\end{array}$ & 0,568 & Valid \\
\hline & & $\begin{array}{c}\text { 4. Diversity Of Traditional } \\
\text { Performing Art }\end{array}$ & 0,511 & Valid \\
\hline
\end{tabular}

Sumber: Hasii Output AMOS, 2014

Berdasarkan tabel di aatas didapatkan hasil second oerder confirmatory factor analysis hasil faktor yang paling dominan membentuk creative tourism terdapat pada creative design, creative performing art karena dari keseluruhan indikator yang telah di estimasi menggunakan confirmatory factor analysis dinyatakan valid memiliki nilai loading factor $>0,5$, sedangkan creative architecture, creative fashion, dan creative culinary terdapat satu indikator dari empat indikator yang yang telah di estimasi menggunakan confirmatory factor analysis dinyatakan tidak valid, maka indikator tersebut dihilangkan dan tidak dapat di ujikan ke proses selanjutnya. Dan untuk creative music dan creative fine art dinyatakan seluruh indikatornya tidak valid karena setelah melakukan estimasi menggunakan confirmatory factor analysis tidak memiliki nilai loading factor > 0,5 maka dinyatakan tidak valid dan variabel creative music dan creative fine art tidak dapat digunakan dalam proses selanjutnya.

\subsection{Tanggapan Wisatawan} Mancanegara terhadap Keputusan Berkunjung dan Dimensinya pada Daerah Istimewa Yogyakarta

Berdasarkan hasil rekapitulasi tanggapan wisatawan Eropa terhadap keputusan berkunjung diatas dapat dilihat bahwa skor total untuk keputusan berkunjung adalah 4.784. Jumlah skor tersebut digambarkan kedalam garis kontinum, yang pengukurannya ditentukan dengan cara:

- Skor Maksimal $=5$ x 12 x $107=6.420$

- Skor Minimum $=1 \times 12 \times 107=$ 1.284

- Jarak Interval $=($ Nilai Indeks Maksimum - Nilai indeks minimum) : $5=(6420$ 1284): $5=1.027$

- Persentase Skor $=[($ total berkunjung skor) : nilai maksimum] $\mathrm{x} 100 \%=$ (4.784:6420) x $100 \%=74,5 \%$

Berdasarkan hasil pengolahan data dari 107 responden, diperoleh total skor dari variabel keputusan berkunjung adalah sebesar 4.816. berikut Gambar 4.17 yang menyajikan posisi keputusan berkunjung wisatawan Eropa ke D.I. Yogyakarta.

Yogyakarta.

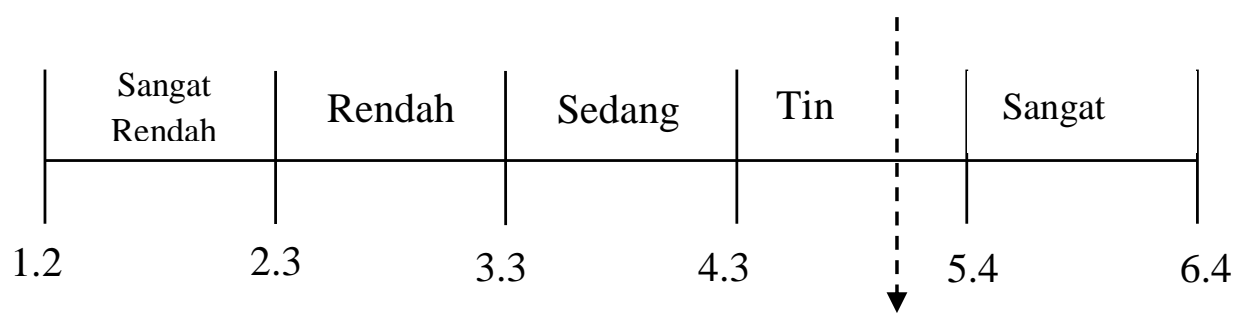

4.78

GAMBAR 4.1 


\section{GARIS KONTINUM VARIABEL KEPUTUSAN BERKUNJUNG WISATAWAN EROPA KE D.I. YOGYAKARTA}

Gambar 4.1 di atas terlihat bahwa gambaran mengenai keputusan berkunjung wisatawan Eropa yang meliputi Negara Belanda, Perancis dan Jerman ke D.I. Yogyakarta secara keseluruhan berada pada posisi yang tinggi. Hal ini membuktikan bahwa wisatawan menanggapi destinasi wisata di D.I. Yogyakarta memiliki daya tarik sehingga wisatawan eropa berkunjung ke destinasi tersebut.

\subsection{Hasil Analisis Uji Keseluruhan} Model Pengaruh Creative Tourism terhadap Keputusan Berkunjung

Berdasarkan rumusan masalah pada penelitian yang dilakukan oleh penulis, bahwa untuk menganalisis pengaruh dari faktor-faktor dominan creative tourism terhadap keputusan berkunjung harus dilakukan beberapa tahapan diantaranya yaitu menguji keseluruhan model, menguji path diagram, menganalisis koefisien korelasi dan determinasi dan tahapan terakhir yaitu melihat seberapa pengaruh creative tourism terhadap keputusan berkunjung dengan menguji siginifikansi secara parsial. Berikut penjelasan mengenai pengaruh faktor-faktor dominan creative tourism terhadap keputusan berkunjung.

\section{Uji Keseluruhan Model}

Dari hasil uji keseluruhan model antara creative tourism terhadap keputusan berkunjung menggunakan program AMOS versi 20 didapatkan hasil sebagai berikut.

TABEL 4.2

KESIMPULAN UJI KECOCOKAN KESELURUHAN MODEL

\begin{tabular}{|c|c|c|c|}
\hline $\begin{array}{l}\text { Ukuran } \\
\text { GOF }\end{array}$ & Tingkat-tingkat kecocokan & $\begin{array}{c}\text { Hasil } \\
\text { Estimasi }\end{array}$ & $\begin{array}{c}\text { Tingkat } \\
\text { Kecocokan }\end{array}$ \\
\hline $\begin{array}{l}\text { Chi-square } \\
\mathrm{P}\end{array}$ & $\begin{array}{l}\text { Nilai yang kecil } \\
\mathrm{P}>0,05\end{array}$ & $\begin{array}{l}97,225 \\
(p=0,001)\end{array}$ & Kurang baik \\
\hline $\begin{array}{l}\text { RMSEA } \\
\text { P (close fit) }\end{array}$ & $\begin{array}{l}\text { RMSEA } \leq 0,08 \\
P \geq 0,05\end{array}$ & $\begin{array}{l}0,08 \\
0,01\end{array}$ & $\begin{array}{l}\text { Baik (good } \\
\text { fit) }\end{array}$ \\
\hline ECVI & $\begin{array}{l}\text { Nilai yang kecil dan dekat dengan ECVI } \\
\text { saturated }\end{array}$ & $\begin{array}{l}\mathrm{M}^{*}=1,540 \\
\mathrm{~S}^{*}=1,717 \\
\mathrm{I}^{*}=3,119\end{array}$ & $\begin{array}{l}\text { Baik (good } \\
\text { fit) }\end{array}$ \\
\hline AIC & $\begin{array}{l}\text { Nilai yang kecil dan dekat dengan ECVI } \\
\text { saturated }\end{array}$ & $\begin{array}{l}M^{*}=163,225 \\
S^{*}=182,000 \\
I^{*}=330,636\end{array}$ & $\begin{array}{l}\text { Baik (good } \\
\text { fit) }\end{array}$ \\
\hline CAIC & $\begin{array}{l}\text { Nilai yang kecil dan dekat dengan ECVI } \\
\text { saturated }\end{array}$ & $\begin{array}{l}M^{*}=284,428 \\
S^{*}=516,227 \\
I^{*}=330,636\end{array}$ & Kurang baik \\
\hline NFI & $\mathrm{NFI} \geq 0,90$ & 0,681 & Kurang baik \\
\hline CFI & $\mathrm{CFI} \geq 0,90$ & 0,83 & marginal fit \\
\hline IFI & IFI $\geq 0,90$ & 0,82 & marginal fit \\
\hline RFI & $\mathrm{RFI} \geq 0,90$ & 0,57 & Kurang baik \\
\hline RMR & Standardized $\mathrm{RMR} \leq 0,05$ & 0,08 & marginal fit \\
\hline GFI & NFI $\geq 0,90$ & 0,88 & marginal fit \\
\hline
\end{tabular}

Sumber: Tabel hasil olahan penelitian, 2014

Dari pembahasan yang telah dilakukan terlihat bahwa ada 4 ukuran Goodness of fit (GOF) yang menungjukkan kurang baik, 5 ukuran menunjukkan kecocokan yang sedang, dan 2 ukuran menunjukkan kecocokan yang baik, sehingga dapat disimpulka keseluruhan adalah sedang (marginal fit).

\section{Pengujian Hipotesis menggunakan Structural Equation Modeling (SEM)}

Penelitian ini menggunakan tingkat kepercayaan $95 \%$ dengan batas p-value 0,05. Dalam uji validitas dan uji reliabilitas sebelum melakukan pengujian model, dua variabel seperti creative music, dan creative fine art tidak diikutsertakan dalam pengujian selanjutnya karena tidak memenuhi syarat pengujian nilai estimasi $<0,5$ dan $\mathrm{p}$-value 
$>0,05$. Serta untuk variabel creative fashion terdapat satu indikator yang tidak diikutsertakan yaitu X3.3 dan variabel creative performing art indikator X6.4 tidak diikutsertakan dalam pengujian selanjutnya. Berikut adalah path diagram hasil uji hipotesis model.

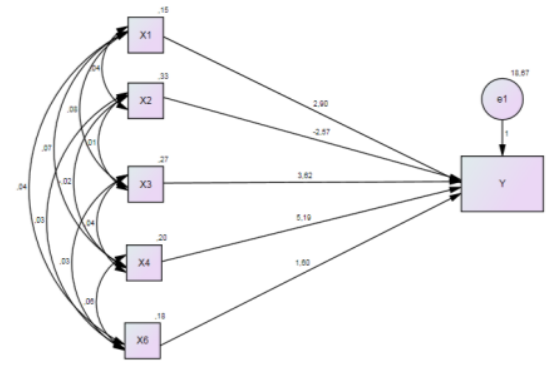

GAMBAR 4.2

STRUCTURAL MODEL ESTIMATES

Hasil Uji Koefisien Korelasi dan Determinasi

Koefisien korelasi berfungsi untuk mengetahui seberapa kuat hubungan variabel creative tourism yang terdiri dari variabel laten yaitu creative architecture, creative design, creative fashion, creative culinary, dan creative performing art dengan keputusan berkunjung. Berikut hasil koefisien korelasi terdapat pada tabel berikut

TABEL 4.3

HASIL UJI KOEFISIEN KORELASI DAN DETERMINASI

\begin{tabular}{|lll|r|}
\hline & & & Estimate \\
\hline $\mathrm{Y}$ & $<-$ & $\mathrm{X}$ &, 507 \\
\hline
\end{tabular}

Sumber: Output AMOS hasil olahan penelitian

Berdasarkan Tabel 4.3 di atas, dari hasil analisis diperoleh nilai koefisien korelasi sebesar 0,507. Merujuk pada interpretasi koefisien korelasi menurut Nugroho (2005:36), nilai 0,507 masuk kedalam interval koefisien 0,41 - 0,70 dengan tingkat hubungan kuat. Hal ini menunjukkan terdapat hubungan yang kuat dari creative tourism terhadap keputusan berkunjung.

Berdasarkan hasil perhitungan diperoleh nilai koefisien determinasi 0,507. Hai ini menunjukkan bahwa besarnya nilai creative tourism terhadap keputusan berkunjung adalah sebesar 0,507 , sedangkan sisanya yaitu 0,443 dikontribusi oleh variabel lain yang tidak diteliti dalam penelitian ini

\section{Pengujian Hasil Uji Signifikansi secara} parsial
Berdasarkan hasil uji hipotesis yang telah dilakukan sebelumnya, tiga dari empat hipotesis penelitian membuktikan adanya pengaruh positif dengan ditunjukkan oleh pvalue sebesar $<0,05$. Secara umum, tabel dibawah adalah kesimpulan hasil uji hipotesis dan disertai estimasi koefisien regresi yang tidak distandarisasikan (unstandardized coeficient). Hasil tabel dibawah mendakan hubungan variabel independen terhadap variabel dependen sebagai hasil struktural second order CFA dengan ditunjukkan oleh output tabel path diagram sebagai berikut.

TABEL 4.4

HASIL UJI SIGNIFIKANSI SECARA

PARSIAL

\begin{tabular}{|l|l|l|r|r|r|r|}
\hline & & & \multicolumn{2}{|c|}{$\begin{array}{l}\text { Estimat } \\
\text { e }\end{array}$} & $\begin{array}{r}\text { S.E } \\
.\end{array}$ & $\begin{array}{r}\text { C.R } \\
.\end{array}$ \\
\hline$Y$ & $\begin{array}{l}<-- \\
-\end{array}$ & $\begin{array}{l}\mathrm{X} \\
1\end{array}$ & 2,900 & 1,298 & 2,233 & $\begin{array}{r}, 02 \\
6\end{array}$ \\
\hline $\mathrm{Y}$ & $\begin{array}{l}<-- \\
-\end{array}$ & $\begin{array}{l}\mathrm{X} \\
2\end{array}$ & 2,575 &, 760 & 3,387 & $* * *$ \\
\hline $\mathrm{Y}$ & $\begin{array}{l}<-- \\
-\end{array}$ & $\begin{array}{l}\mathrm{X} \\
3\end{array}$ & 3,619 &, 883 & 4,097 & $* * *$ \\
\hline $\mathrm{Y}$ & $\begin{array}{l}<-- \\
-\end{array}$ & $\begin{array}{l}\mathrm{X} \\
4\end{array}$ & 5,189 & 1,081 & 4,801 & $* * *$ \\
\hline $\mathrm{Y}$ & $\begin{array}{l}<-- \\
-\end{array}$ & $\begin{array}{l}\mathrm{X} \\
6\end{array}$ & 1,599 & 1,056 & 1,514 & $\begin{array}{r}13 \\
0\end{array}$ \\
\hline
\end{tabular}

Sumber: Output AMOS hasil olahan penelitian

Berdasarkan Tabel 4.12 di atas, secara parsial menunjukkan bahwa tidak semua variabel bebas creative tourism memiliki signifikansi kurang dari 0,05, artinya variabel tersebut tidak berpenngaruh terhadap keputusan berkunjung. Hasil analisis menunjukkan satu variabel tidak berpengaruh yaitu creative performing art (X6).

\subsection{Implikasi Hasil Penelitian}

\subsubsection{Temuan Penelitian bersifat Teoritik}

1. Dalam konsep creative tourism ini, penulis membuat pengukuran sendiri mengenai faktor-faktor dominan apa saja yang dapat membentuk creative tourism di Indonesia khususnya di D.I. Yogyakarta, pengukuran tersebut diambil dari gagasan yang dijelaskan oleh Renstra Kemenparekraf 2011-2015, variabel laten tersebut adalah creative architecture, creative design, creative fashion, creative culinary, creative music, creative performing art, dan creative fine art dimana variabel laten 
tersebut di ujikan dengan menggunakan confirmatory factor analysis.

2. Berdasarkan temuan penlitian, penulis memperkuat konsep keputusan berkunjung menurut Hollensen (2010:117-118) mendeskripsikan bahwa keputusan pembelian dapat dipengaruhi oleh psychological seseorang karena manusia memiliki pandangan yang berbeda mengenai suatu kebutuhan yang ingin dipenuhinya. Varibel keputusan berkunjung (Y) memiliki empat dimensi menurut yaitu need, perception, memory dan attutudes.

3. Berdasarkan temuan penlitian, penulis memperkuat konsep creative tourism terhadap keputusan berkunjung seperti yang telah dikemukakan oleh Olson and Ivanov (2010) dalam jurnalnya menjelaskan bahwa untuk meningkatkan wisatawan domestik atau internasional tidak cukup hanya dengan sebuah rencana atau program saja. Pemasaran yang kuat, regionaland local branding harus mampu menciptakan sebuah sentuhan kreatif yang menjadi salah satu pilihan agar bisa meningkatkan kunjungan wisatawan dan dapat menyumbang devisa pada negara.

\subsubsection{Temuan Penelitian Bersifat} Empirik

1. Program wisata yang bertemakan creative tourism di D.I. Yogyakarta dibentuk oleh faktor industri kreatif yaitu creative architecture, creative design, creative fashion, creative culinary, creative music, creative performing art, dan creative fine art. Dan berdasarkan hasil yang di temukan penulis bahwa faktor pembentuk yang paling dominan adalah creative culinary, creative fashion, creative design, dan creative architecture.

2. Keputusan berkunjung yang terdiri dari need, perception, memory dan attitudes, dimana dimensi yang paling tinggi nilainya yaitu attitudes hal ini dikarenakan wisatawan senang berkunjung ke D.I. Yogyakarta dimulai dengan kebutuhan wisatawan untuk berwisata, mempersepsikan D.I. Yogyakarta memiliki destinasi wisata yang beragam dan memiliki daya tarik, ingatan yang indah ketika berkunjung ke beberapa destinasi sehingga wisatawan eropa setelah kembali ke negaranya masing-masing merekomendasikan kepada keluarga, kerabat dan sahabatnya untuk memilih D.I. Yogyakarta sebagai destinasi wisata pilihan ketika berlibur.

3. Berdasarkan penelitian secara empirik telah didapatkan hasil faktor creative tourism apa saja yang mempengaruhi keputusan berkunjung wisatawan Eropa ke D.I. Yogyakarta, dari hasil pengujian didapatkan dari lima variabel laten creative tourism yang terdiri dari creative architecture, creative design, creative fashion, creative culinary dan creative performing art, satu variabel yang tidak berpengaruh positif terhadap keputusan berkunjung yaitu creative fine art, sedangkan variabel laten lain yaitu creative architecture, creative design, creative fashion dan creative culinary berpengaruh positif terhadap keputusan berkunjung.

Berdasarkan hasil temuan-temuan tersebut di atas, maka penelitian ini diyakini mampu memberikan sumbangsih ilmiah bagi pengembangan ilmu manajemen peamasaran pariwisata khusunya yang berkaitan dengan destinasi wisata berbasiskan creative tourism. Selain itu juga, penelitian ini dapat dijadikan masukan yang konstruktif dan inspiratif bagi Kemenparekraf dan Dinas Pariwisata D.I. Yogyakarta .

\section{KESIMPULAN DAN SARAN}

\subsection{Kesimpulan}

Berdasrkan hasil penelitian yang telah dilakukan dengan menggunakan analisa deskriptif dan verifikatif antara creative tourism terhadap keputusan berkunjung wisatawan Eropa ke D.I. Yogyakarta dapat diambil kesimpulan sebagai berikut.

1. Secara umum faktor-faktor dominana yang dapat membentuk creative tourism D.I. Yogyakarta terdiri dari tujuh variabel laten dan 28 indikator, variabel laten tersebut adalah creative architecture, creative design, creative fashion, creative culinary, creative music, creative performing art dan creative fine art. Setalah melakukan confirmatory factor analysis didapatkan hasil faktor yang paling dominan terdapat pada creative fashion yang terdiri dari tiga indikator yaitu diversity of traditional fashion, design of traditional fashion dan traditional fashion have good quality. Sedangkan faktor yang terendah dalam pembentuk creative tourism adalah creative music. 
2. Secara umum gambaran keputusan berkunjung wisatawan eropa yang terdiri dari Negara Belanda, Perancis dan Jerman ke D.I. Yogyakarta memiliki respon yang tinggi. Penilaian terhadap keputusan berkunjung wisatawan dinilai dari empat dimensi yaitu need, perception, memory dan attitude. Jawaban responden menunjukkan hasil bahwa dimensi yang dengan penilaian tertinggi dan memiliki pengaruh besar terhadap keputusan berkunjung yaitu attitudes. Hal ini dikarenakan wisatawan senang berkunjung ke D.I. Yogyakarta dimulai dengan kebutuhan wisatawan untuk berwisata, mempersepsikan D.I. Yogyakarta memiliki destinasi wisata yang beragam dan memiliki daya tarik, ingatan yang indah ketika berkunjung ke beberapa destinasi sehingga wisatawan eropa setelah kembali ke negaranya masing-masing merekomendasikan kepada keluarga, kerabat dan sahabatnya untuk memilih D.I. Yogyakarta sebagai destinasi wisata pilihan ketika berlibur.

3. Berdasarkan pengujian hipotesis dengan teknik SEM (Stractural Equation Modeling) yang bertujuan untuk memastikan model yang digunakan adalah baik maka dapat dihasilkan bahwa model yang digunakan untuk mengatahui pengaruh creative tourism terhadap keputusan berkunjung terlihat dari pembahsan yang telah dilakukan bahwa ada 4 ukuran Goodness of fit (GOF) yang menunjukkan kurang baik yaitu pengukuran chi-square, CAIC, NFI, dan RFI, sedangkan 4 ukuran menunjukkan kecocokan yang sedang yaitu pengukuran CFI, IFI, RMR dan GFI dan 3 ukuran menunjukkan kecocokan yang baik yaitu pengukuran RMSEA, ECVI dan AIC, sehingga dapat disimpulkan keseluruhan model adalah sedang/cukup baik (marginal fit). Setalah melakukan proses pengukuran model maka dijadikan untuk path analysis dimana seluruh variabel laten creative tourism diujikan terhadap keputusan berkunjung dan dapat dihasilkan bahwa dari kelima variabel laten tersebut satu variabel laten creative performing art tidak memiliki pengaruh positif terhadap keputusan berkunjung. Pengaruh creative culinary terhadap keputusan berkunjung adalah yang paling tinggi.
Berdasarkan hasil penelitian yang dilakukan, maka penulis merekomendasikan beberapa hal yang dapat dipertimbangkan oleh Kemenparekraf dan Dinas Pariwisata D.I. Yogyakarta, berikut rekomendasi yang diajukan:

1. Pelaksanaan program wisata yang bertemakan creative tourism yang diselenggarakan pada tahun 2011-2015 ini bertujuan untuk meningkatkan kunjungan wisatawan mancanegara ke Indonesia, D.I. Yogyakarta merupakan salah satu destinasi yang ditujukan untuk mengembangkan program wisata yang bertemakan creative tourism tersebut, penulis merekomendasikan kepada Kemenparekraf dan Dinas Pariwisata DIY agar memberikan pengetahuan dan sosialisasi mengenai tema pariwista creative tourism karena sangat di sayangkan program tersebut sangat efektif dan efisien di lakukan sebagai promosi pariwisata Indonesia ke luar negeri namun banyak sekali masyarakat Indonesia bahkan pelaku wisata pun masih tidak aware dengan tema pariwisata creative tourism, namun pada dasarnya hampir disemua daerah di D.I. Yogyakarta telah merealisasikan tema tersebut terlihat dari banyaknya tempat yang menyediakn untuk wisatawan tinggal di salah satu desa dan mereka bisa merasakan kehidupan masyarakat lokal, karena telah diketahui bahwa creative tourism adlah peran partisipasi aktif wisatawan yang berkunjung ke suatu daerah/tempat dengan tinggal di tempat tersebut dan merasakan pengalaman dan pembelajaran menganai kearifan budaya lokal setempat. Oleh sebab itu semoga program creative tourism bisa diselenggarakan lagi di tahun selanjutnya karena telah terbukti dari penenelitian ini terdapat pengaruh yang positif antara creative tourism yang terdiri dari creative architecture, creative design, creative fashion dan creative culinary.

2. Secara keseluruhan, wisatawan Eropa yang meliputi Negara Belanda, Perancis dan Jerman memiliki penilaian mengnai creative tourism dengan baik hanya saja ada beberapa faktor yang tidak dapat dijadikan pengukuran selanjutnya yaitu creative music dan creative fine art, Oleh sebab itu penulis merekomendasikan kepada Kemenparekraf dan Dinas Pariwisata

\subsection{Saran}


D.I. Yogyakarta agar bisa lebih mengangkat musik tradisional Indonesia kehadapan wisatawan Mancanegara karena dengan intensitas promosi yang gencar dilakukan seperti mendaftarkan alat atau instrumen musik tradisional ke UNESCO maka akan membuat wisatawan mancanegara aware dan memiliki rasa penasaran untuk mencoba memainkan atau mendengarkan musik tradisional Indonesia dan seri rupa Indonesia juga harus lebih menarik sehingga wisatawan mancanegara melirik dan menginginkan benda yang kaya akan warisan budaya Indonesia.

3. Hasil penelitian menunjukkan dari kelima variabel laten creative tourism, creative performing art adalah varibel laten yang tidak berpengaruh terhadap keputusan berkunjung karena dirasakan creative performing art tidak bisa berdiri sendiri sebagai variabel laten, oleh sebab itu penulis merekomendasikan agar creative performing art dapat disatuan dengan unsur musik, tari, teater, dll agar menajdi kesatuan pernampilan yang utuh dan dapat menarik minat wistawan mancanegara untuk melihat dan berkunjung ke suatu destinasi wisata tersebut, selain wisatawan bisa melihat penampilan tersbut secara tidak nampak hal tersebut dapat dijadikan suatu promosi pariwisata Indonesia di mata wisatawan mancanegara.

4. Setiap penelitian tentunya memiliki kekurangan dan keterbatasan, begitu pula dengan penelitian yang memiliki keterbatasan dalam menganalisis faktorfaktor dominan apa saja yang membentuk creative tourism yang hanya dilihat dari indikator Kemenparekraf. Sebagai bahan rekomendasi, untuk para peneliti selanjutnya dalam meningkatkan kunjungan wisatawan mancanegara ke Indonesia pada umumnya dan khusunya di D.I. Yogyakarta dapat melakukan penelitian yang mencakup promosi pariwisata Indonesia dengan tema low season tourism karena hal tersebut saat ini sedang digencarkan oleh pemerintah khusnya oleh Kemenparekraf.

\section{DAFTAR PUSTAKA}

Arbucle, James L. 2012. IBM, SPSS, AMOS

21 user's guide. Amos Development Corporation. All Rights Reserved. Licensed Materials - Property of IBM
Bowie, David dan Francis Buttle. 2004. Hospitality Marketing. Oxford: Elsevier Ltd. (e-book)

Burnett, Jhon. 2008. Core Concept of Marketing. Zurich- Switzerland: Jacob Foundation

Buttle, Francis A. 2008. Word of mouth: understanding and managing referral marketing. Journal Of Strategic Marketing, p.1.

Cakim, Idil M. 2010. Implementing Word Of Mouth Marketing. New Jersey: John Wiley \& Sons, Inc. (e-book)

Chang, Lee \& Huang. 2008. The Influence of E-Word-Of-Mouth on the Consumer's Purchase Decision: a Case of Body Care Products. p. 1

Copley, Paul. 2006. Marketing Communication Management: Concepts and Theories, Cases and Practices. Oxford: Elsevier. (e-book)

Enz, Cathy A. 2010. Hospitality Strategic Management. New Jersey: John Wiley \& Sons, Inc. (e-book)

Ferdinand, Augusty. 2002. Structural Equation Modeling Dalam Penelitian Manajemen, Aplikasi Model-model Rumit dalam peneletian untuk Tesis dan Disertasi, Semarang: Badan penerbit Universitas Diponogero

Greg and Richard. 2006. creative tourism; art \& culture; creative cities; intangible cultural heritage; UNESCO; science museum; inclusive museum; learning style. UNESCO

Fill, Chris. 2009. Marketing Communications: Interactivity, Communities and Content Fifth Edition. England: Prentice Hall. (ebook)

Hair. 2006. Multivariate Data Analysis 6E. England: Prentice Hall

Hollensen, Svend. 2010. Marketing Management a Relationship Approach. London: Prentice Hall. (ebook)

Kirby, Justin dan Paul Marsden. 2006. Conected Marketing: The Viral, Buzz and Word of Mouth Revolution.Oxford:Elsevier Ltd. (ebook)

Kotler, Philip dan Gary Armstrong. 2012. Principles of Marketing 14th Editions. New Jersey: Prentice Hall. (e-book)

Kotler, Philip dan Kevin Lane Keller. 2012. Marketing Management 14th 
Editions. New Jersey: Prentice Hall. (e-book)

Kotler, Philip et al. 2009. Marketing Management. London: Prentice Hall. (e-book)

Lamb, Hair, dan Carl McDaniel. 2011. Marketing. United States: SouthWestern Cengage Learning. (e-book)

Lamb, Hair, dan Carl McDaniel. 2011. MKTG5.United States: SouthWestern Cengage Learning. (e-book)

Mahotra, Naresh K. 2009. Marketing: An Appplied Orientation. United Kingdom: Person Edition

McCabe, Scot. 2009. Marketing Communicatons in Tourism and Hospitality: Concepts, Strategies and Cases. Oxford: Elsevier Ltd. (e-book)

Mike Ride, et al. 2008. Marketing of Protected Area as a Tool to Influence Visitors Pre-Visit Decisions. Australia (Gold Coast, Queensland): CRC for Sustainable Tourism Pty Ltd

Morrison, Alastair M. 2010. Marketing and Managing Tourism Destination. Routledge. Francis Group

Pike, Steven. 2008. Destination Marketing: An Integrated Marketing Communication Approach. (e-book)

Pitana dan Diarta. 2009. Pengantar Ilmu Pariwisata. Andi Publishing. Yogyakarta

Ricahard and Wilson.2007. Tourism Creativity and Development, 2007 Routledge, USA and Canada

Sugiyono. 2010. Metode Penelitian Kuantitatif dan Kualititatif. Alfabeta. Bandung

Sugiyono. 2009. Metode Penelitian Bisnis. Alfabeta. Bandung

Sugiyono. 2010. Metode Statistika untuk Penelitian. Alfabeta. Bandung

Stolarick, Kevin. 2012. Creativity, Tourism and Economic Development in a Rural Context: the case of Prince Edward County. United States

U.E. Wardhani, dkk. 2008. Usaha Jasa Pariwisata. Departemen Pendidikan Nasional. PT. Mancanan Jaya Cemerlang. Klaten Utara.

\section{Journal and Others}

Anggi Rahajeng. 2008. Analisis Faktor Keputusan Wisata Budaya, Sejarah dan Alam Yogyakarta: Persepsi Wisatawan Domestik. Pusat studi Ekonomi dan kebijakan publik. UGM
Annual Report, Strategic Plan Badan Promosi Pariwisata Indonesia 20112015

Annual Report, Strategic Plan Kementrian Pariwisata dan Ekonomi Kreatif, 2011-2015

Buku Statistik Kepariwistaan DIY. 2012

Bergadaa, Michelle. 2008. of Art, and Their Craft: The Experience of Authenticity and Its Materialization in the Places where craftspeople and Enlightened clients meet. Recherche et Applications en Marketing (English Edition) 2008 23: 5

Chang, Kenneth F. Backman. An investigation creative tourist experience and revisit intention. Department of Park, recreation and Tourism Management. Clemson University

Creative cities network. 2008. Toward sustainable strategies for creative tourism. Discussion report of the planning meeting International Conference on Creative tourism. Mexico, USA

Diana D. Suhr. --. Statistic Data Analysis. Explortory or ConfirmatoryFactor Analysis. University of Northern Colorado

Ekonde, Cathy. N. 2010. Tourism destinaton marketing. A comparative study between Gotland Island, Sweden and Limbe city, Cameroon. Bo Lennstrand: Gotland University

Edwin Japarianto. --. Analisa Faktor Type Hedonic Shopping Motivation dan Faktor Pembentuk Kepuasan Tourist Shopper di Surabaya. Fakultas Ekonomi. Universitas Kristen Petra

Emilova, Irena. ---. Creative dimmensions in the tourist industry. New Bulgarian University.

Friendly, Michael. --. Exploratory and Confirmatory Factor Analysis. Presentation of Psychological.

Greg, Richards and Lenia Marques. 2012. Exploring creative tourism: Editors Introduction. Journal of Tourism Consumption and Practice Volume 4 No.2 2012

Greg , Richard. 2010. Creative tourism: Development, trends and opportunities. Tilburg University. Barcelona

Hemmati, Roshan Babaee and Bijan Abbasi. 2013. Creative tourism entrepreneurship in Rasht. MA of 
Department of Research

Guilanology,Guilan University

Hendry. 2013. Confirmatory Factor Analysis (Analisis Faktor Konfirmatori) : Dengan Lisrel Dan Amos. Jakarta

Jelencic, Daniela Angelina and Zuvela, Ana. 2012. Facing the challenge? Creative tourism in Croatia. Journal of Tourism Consumption and Practice.

Justin, Marta. 2012. Creativity in the JoHari window: An alternative model for creating tourism programmes. Journal of Tourism Consumption and Practice Volume 4 No 22012

King, Brad. _. Creative Tourism and Cultural Development: Some Trends and Observations. Management Consultancy. Lord Cultural Resources

Korez, Romana-Vide. --. Promoting sustainability of tourism by Creative tourism Development. Innovative Issues and Approaches in Social Sciences, Vol. 6, No. 1

Marques, Lenia. 2012. Boosting potential creative tourism resources: The case of Siby (Mali). Journal of Tourism Consumption and Practice Volume 4 No 22012

Marzursky, David. 1989. Past Experience and Future Tourism Decisions. Annual of Tourism Research, Vol 16, pp. 333-334, 1989. USA: Prentice Hall

Richard and Wilson. 2006. Developing Creativity in Tourist Experienc: A Solution to the Serial Reproduction of Culture

Salerno, Annabel. 2009. Consumer creative experience: The role of motivational orientation in Creative Leisure Activit. Recherche et Applications en Marketing (English Edition) vol. $25 n$ 1/2009

Siow-kian Tan, et. All. 2013. A Model Of 'Creative Experience' In Creative Tourism. Annals of Tourism Research, Vol. 41, pp. 153-174, 201. Printed in Great Britain

Suliyanto. --. Structural Equation Modeling (SEM). Presentasi Ilmiah

Setyo Hari Wijanto. 2008. SEM dengan LISREL 8.8. Yogyakarta : Graha Ilmu

Stolarick, et.al. 2010. Creativity, Tourism and Economic Development in a Rural Context: the case of Prince Edward County. Journal of Rural and Community Development 5, 1/2 (2010) 238-254

Ohridska, Stanislav, Ivanov. 2010. Creative Tourism Business Model And Its Application In Bulgaria, Journal Marketing.

Ozen Kirant, Yozcu dan Orhan Icoz , 2010. A Model Proposal on the Use of Creativity Tourism Experience in Congress Tourism and the Congress Marketing Mix

Rossitza Ohridska-Olson and Stanislav Ivanov. 2010. Creative Tourism Business Model And Its Application In Bulgaria

Romana Korez-Vide. 2010. Promoting Sustainability of Tourism By Creative Tourism Development: How Far Is Slovenia?

Vanessa Gaffar, et. All. 2011. Comparative Study Of Tourist Characteristics On Cultural Heritage Tourism Sites: Survey On Tourist In Indonesia And Thailand Heritage Sites. Tourism Marketing Management-UPI. Indonesia

Wahyu Widhiarso. 2009. Praktek Model Persamaan Struktural (SEM) Melalui Program AMOS. Fakultas Psikologi UGM. Yogyakarta

Tourism Barrometer, UNWTO Volume 11 Januari 2013

Tourism Barrometer, UNWTO Volume 11 Juni 2013

Tourism Barrometer, UNWTO Volume 11 Agustus 2013

Undang-Undang Kepariwisatataan Indonesia No. 10 Tahun 2009

World Travel \& Tourism Council. 2011. Lisbon The Impact of Travel and Tourism on Jobs and The Economy.

\section{Websites}

http://www.thejakartapost.com/news/2012/0 1/11/asean-tourism-ministers-discusscreative-tourism.html. diakses pada 02 April 2013 15:26

http://justanotherwordpress.com/sumber daya pariwisata. Diakses pada bulan Maret 2013 jam 20:31 WIB

http://scribd.com/doc/13405338/ujikorelasi. Diakses pada tanggal 20 Desember 2012 Jam 18.22

http://detik.com/ Ini Alasan 4 Kota Kreatif di Indonesia Didaftarkan ke UNESCO. Diakses pada tanggal 27/02/2014 jam 10:48 
http://visitingjogja.gov.id. Profil, Sejarah, dan Tren Pariwisata Daerah Istimewa Yogyakarta. Diakses pada 25 Maret 2013 jam 22:34 